\title{
Diabolus ex Machina: Bulgakov's Modernist Devil
}

\section{Vladimir Tumanov}

Department of Modern Languages and Literatures, Western University, London, ON N6A 3K7, Canada e-mail: vtumanov@uwo.ca

Scando-Slavica

1989 (35): 49-61

DOI: $10.1080 / 00806768908600949$ 


\section{Diabolus ex Machina: Bulgakov's Modernist Devil ${ }^{1}$}

In 1937, when Bulgakov was working on Master $i$ Margarita and suffering from rejection by the theatre community, an old friend appealed to him: "Вы ведь государство в государстве. Сколько это может продолжаться? Надо сдаваться, все сдались. Один вы остались. Это глупо." ${ }^{2}$ And indeed "государство в государстве" ("a state within a state") is an appropriate way of describing a man who was feverishly working on a modernist novel at the height of socialist realism. The very fact that Master i Margarita was written in the oppressive environment of the 1930s makes it a unique modernist work, for it emerges as a protest against socialist realism and a defense of artistic freedom. In this respect the modernist qualities of Bulgakov's novel acquire a new dimension because Master i Margarita becomes a kind of artistic devil, fulfilling the traditional diabolic role of opposing authority. This is why Woland, as a character, is the metonymic expression of the novel's revolt.

The role and significance of Woland in Bulgakov's Master i Margarita has been debated ever since the first publication of the novel in 1966-1967. He is "a god of vengeance" to Ellendea Proffer (556), "on the side of the angels" for A. Colin Wright (269) and the "Archangel of the Master i Margarita", to use Kalpana Sahni's metaphor (195). The one thing that most critics seem to agree on is that the devil's role is central in Master i Margarita, and the general reader appears to be of the same opinion, as John Bushnell concludes from his readerresponse study. Bushnell examined the graffiti related to Master i Margarita on the walls around apartment 50 at Большая Садовая 10 in Moscow where Bulgakov had lived in the early 1920 s and where Woland resides during his brief stay in Moscow: "To the graffiti writers, and the many nonwriters whose views they represent, the novel is about Woland and his assistants" (510).

\footnotetext{
${ }^{1}$ Published article here: http://www.tandfonline.com/doi/abs/10.1080/00806768908600949

2 "You are a state within a state. How long can this go on? Give it up - everyone has. You're the last man standing. Not a smart idea!" (Shvartz, 96 - my translation, V.T.)
} 
Bushnell goes on to argue that in the popular imagination the devil seems to have crowded out almost entirely both the Master and Margarita, as well as the Pilate chapters. The question is why?

Julie Curtis, for example, thinks that "[Woland is the source of] direct continuity between the world of Pilate and modern Moscow" (168). And I would like to carry this a step further: by giving Woland a thorough cultural and historical grounding in the past and then placing him in a modern setting, Bulgakov created a modernist devil. Woland is a slap in the face of socialist realism which wanted nothing to do with the past or the supernatural. And as a modernist devil, Woland becomes an artistic means of escape from mediocrity. Through Woland, Bulgakov did what he could never do in real life: he created a feeling of freedom and control of one's destiny, and, as Lesley Milne points out, "man was never less in control of his personal fate than he was in Russia of the 1930s" (24). Woland is a definite redeemer, playing a messianic role in a wicked society where nothing short of a supernatural power can alter the course of events. Thus, Bulgakov's devil appears as an allegory for spiritual, artistic and physical liberation.

The choice of the devil to play this role is most appropriate, since Lucifer, by rebelling against God, was the first being to assert his own individuality and to free himself from the first dogma: God's hierarchy. Hannes Vatter argues that "in separating himself from the totality of God, [Lucifer] establishes an identity of his own... This process of individuation is particularly important for all forms of artistic creation" (17). The devil is the first non-conformist in the JudeoChristian tradition, and, as A. Colin Wright puts it, "here we find the key to the whole book for, as we have seen, it is the individual non-conformists who are Bulgakov's heroes, those who rebel - whether against God or man" (270). And indeed who could be a better liberator than the being that was the first to liberate itself? 
This biblical side of Woland is supplemented by his medieval carnivalesque features (see Bakhtin). Discussing the sources of Rabelais's humor, Bakhtin turns to the medieval public place where times of carnival often involved the mockery or parody of official culture condoned by the church and the political authorities. Frequently mock religious ceremonies would take place during carnival, complete with mock processions and mock liturgies. This was a form of cultural liberation in the Middle Ages, and it is this kind of liberation that Woland allegorizes in Master i Margarita. John Bushnell sees Woland's behavior as "a carnivalesque assault on dogma and authority... turning the natural and social orders of things on their heads" (510). And indeed Woland is the spirit of medieval carnival come to Stalinist Moscow: he mocks and dethrones the 'high priests' of the 'communist religion', which are the socialist realist literary and theatre establishments; he makes the NKVD and its attempts to arrest him look totally ridiculous, and the NKVD is the representative of the system's political power; by resurrecting the Master's novel he mocks Soviet censorship, which is the main tool of cultural and ideological oppression; and finally Woland redeems the person who has been 'damned' by the official cultural and political establishments - the honest artist. Thus, like medieval man, who acted out during carnival his urge to be free, Bulgakov acts out the same urge on the pages of his novel through his modernist devil in medieval clothing. And like medieval man, Woland does this by turning the official world upside down.

The spirit of carnivalesque liberation is especially evident at Satan's spring ball which is of course an obvious allusion to the Walpürgisnacht in Goethe's Faust. The roots of the Walpürgisnacht concept itself are believed to go back to pagan fertility rites, which were themselves a form of carnival, a release of human drives normally suppressed by socialization or a sort of liberation from the social contract (Milne: 24). And it is precisely this type of liberation that is celebrated at Woland's spring ball. The concept of release is accentuated all the more because the ball takes place against the background of Soviet repression, which could be viewed as an extreme form of socialization. At the ball, taboos 
are violated as women prance about naked, the guests swim in pools of liquor and champagne, criminals are warmly welcomed and honored and a man is murdered in the finale.

All this illustrates why Bulgakov turned to the rich sources of the past when creating the character of Woland, relying on everything from Judeo-Christian scripture to medieval concepts to romanticism. He had grown up with Gounod's opera Faust (Milne: 30), and indeed in the third draft of the novel he even refers to one of his characters as Faust (Proffer: 527). And so it is no wonder that Master i Margarita abounds with references to Goethe's work where god and the devil bet on whether a man called Faust can be led astray. To begin with, the name Voland is one of the names used by Mephistopheles in reference to himself during the Walpürgisnacht ("Junker Voland"-Faust, II, v. 4021-4025). Gretchen (German equivalent of Margarita) is Faust's sweetheart in Part I. Just as Goethe's Mephistopheles enters the stage in the form of a poodle, Bulgakov's Woland makes his first entrance, carrying a cane with a nob in the shape of a poodle's head. The head of a poodle is also on the picture hung in a heavy oval frame on Margarita's neck at Satan's spring ball in Master i Margarita. There is a number of other similar allusions in Bulgakov's novel, but the most obvious connection with Faust is the epigraph taken directly from Goethe's work where the devil is called a force that "stets das Böse will und stets das Gute schafft". This epigraph is the most important thematic link between Mephistopheles and Woland because it indicates that we are not dealing with a traditional devil intent on causing man's downfall.

Goethe's romantic Mephistopheles and Bulgakov's modernist Woland are not Satan in the Hebrew sense of "God's adversary"; they are both accepted as being complementary to God (Vatter: 27). Just as Faust's God looks kindly on Mephistopheles and allows him to conduct his "experiment", Bulgakov makes Woland god's assistant, which is why the devil willingly carries out Yeshua's request to give Master and Margarita peace. Thus, by alluding to Faust (and 
thereby to the Book of Job - Goethe's source for the wager between god and the devil), Bulgakov creates a devil who is an observer of human behavior, a sort of behavioral scientist, rather than an evil spirit. His main trait is curiosity although further on in the novel we also witness Woland's compassionate side.

The members of Woland's entourage are also references to past myths. Behemoth is a hippopotamus-shaped demonic beast referred to in the Book of Job (XL. 15-24). Azazello, the Italianized version of the Hebrew Azazel, is the demon of the desert from Leviticus (XVI 8ff.). Azazel is, incidentally, also the word for devil in modern Hebrew. Abadonna is from Abaddon, the destroyer from the book of Revelation (IX. II). Koroviev, whose name is derived from "корова" ("соw" in Russian), may be an allusion to the Golden Calf cult of the Canaanites in the Old Testament (Natov: 98). All these characters symbolize the various ways in which the devil has been viewed in the Judeo-Christian tradition and pagan myths, which is why I do not see them as being separate from Woland. They are his alter egos - allusions to the rich devil lore of our civilization. However, all this cultural grounding is but a means to an artistic end in Master i Margarita or, as Kalpana Sahni says: "There is no idealization of the past but rather, an attempt to reintegrate myths to contemporaneity" (187).

The devil's role as liberator is first of all stressed by his own foreignness and the foreignness of his beneficiaries: the Master and Margarita. This foreignness can be best described by the French word étranger, which has two meanings: a) a person from a different country and b) a person or thing which does not belong to or is out of place in any given group. It is this second "out of place" sense that appears important here because the truly foreign aspect of the devil, as well as the allusive foreignness of the two lovers, is paralleled by the ideological foreignness of all three in Soviet society. As a foreigner, Woland brings with him the wind of West European freedom and culture to the mental dungeons of Russia - a freedom that is desperately sought by the Master, by 
Margarita and by Bulgakov himself. Right from the beginning, it becomes obvious that we are not dealing with a Russian devil. Both Ivan and Berlioz, as mistrustful of foreigners as everyone else in Russia of the 1930s, note immediately that Woland looks foreign: "Немец... - подумал Берлиоз. Англичанин... - подумал Бездомный" (Bulgakov, 1969: 15). Alluding to his Faustian roots, Woland tells them that he is German.

Just like Woland and his entourage, the two lovers have names of foreign origin; and as for Margarita, her foreignness, apart from her alienation from Soviet society, is also suggested by the fact that she is a descendant of the 16th century French queen, Marguerite de Navarre (1492-1549) (Bulgakov, 1969: 320). The subject of the Master's novel is foreign to socialist realism in that it is antidogmatic. The Master is especially foreign in the second sense of the word étranger because he does not really understand the society that he lives in: he actually believes at first that his novel about Pontius Pilate and Jesus Christ can be published in the violently atheistic and paranoid Soviet Union of the 1930s. Bulgakov himself was not that naive; although for a time he did entertain a glimmer of hope about the publication of Master i Margarita, he quickly gave it up when I. Ilf and E. Petrov offered to print it in Ogonek... on the condition that the Pilate chapters be removed. He said to his wife in 1938: "Вероятно, ты уложишь роман в бюро или в шкаф, где лежат убитые мои пьесы, и иногда будешь вспоминать о нем." (Shwartz: 103-108). Of course the consequences of the Master's attempt to have his novel published reflect the public hounding and rejection suffered by Bulgakov in the socialist realist literary world of the 1930s.

The devil's foreignness, along with the freedom that he brings and represents, is frequently juxtaposed with various aspects of Soviet reality, creating a carnivalesque-official antithesis. A very striking contrast is achieved through language: the devil's uninhibited natural speech is pitted against the severely constrained language of Soviet officials and bureaucrats. This linguistic 
incompatibility can be observed in the devil's encounters with such typical Soviet bureaucrats as Andrei Fokich Sokov, the head barman from the Variety Theatre, and Nikolai Ivanovich, Margarita's neighbor. In the last instance, these incompatible linguistic elements are woven into one absurd document drawn up by Behemoth at Nikolai Ivanovich's request for official proof of his presence at Satan's spring ball: "Сим удостоверяется, что предъявитель сего, Николай Иванович, провел упомянутую ночь на балу у сатаны, будучи превлечен туда в качестве перевозочного средства... 'боров'. Подпись Бегемот" (Bulgakov, 1969: 368). This document is carnivalesque because its content subverts its form, which is made even more absurd when the cat stamps the document with a totally irrelevant "уплочено" (a grammatically incorrect but wide-spread way of saying "paid" in Russian).

A similar carnivalesque-official juxtaposition is achieved when Woland, after predicting the impending death of Andrei Fokich Sokov, advises him not to bother with a hospital and doctors but "устроить пир... и принять яд, переселиться в другой мир под звуки струн, окруженным хмельными красавицами и лихими друзьями" (Bulgakov, 1969: 263). Once again the carnivalesque nature of this advice is contrasted with the stale, inhibited, bureaucratic, Soviet nature of the man to whom this advice is given. One is tempted to liken this scene to an encounter between Mephistopheles and a Soviet version of Gogol's Акакий Акакиевич from "The Overcoat." And the same sort of carnivalesque-official incongruity is observed when Hella hands Andrei Fokich Sokov a sword, along with his hat, as he is about to leave Woland's apartment: "- Не мое... - шепнул буфетчик, отпихивая шпагу и быстро надевая шляпу... - Разве вы без шпаги пришли? - удивилась Гелла" (Bulgakov, 1969: 265).

The poetic-romantic sword symbol subverts the mundane hat symbol, mocking the boring and stale nature of Soviet society. Furthermore, the little homo sovieticus finds the sword so foreign, that he cannot even bring himself to 
name it. To him the sword is so perplexing that he refers to it, using the ambivalent neuter form indicating that he is unable to even utter a carnivalesque (and therefore liberating) word.

On the most superficial level, the traditional legendary aspect of the devil is a means of liberation from the constraints of the physical world. He frees Margarita from the constraints of time and space by restoring her youth and giving her the power to fly at incredible speeds, which is a clear allusion to Mephistopheles's first two gifts to Faust. Similarly, time and space are totally overlooked at Woland's splendid spring ball which begins and ends at the moment of midnight in Likhodeiev's small Moscow apartment and yet seems to go on forever in seemingly boundless quarters. Time is experienced at Woland's ball in the Bergsonian sense of durée: it is felt and lies outside the bounds of physical time. In the same 'diabolical' manner, Bulgakov creates the impression that a very long time passes between Woland's arrival in Moscow and his departure whereas actually his meeting with Berlioz takes place on Wednesday, and his departure with the Master and Margarita on the following Saturday. Through Woland's invulnerability, the reader vicariously enjoys the sheer pleasure of being outside the reach of the physically oppressive Soviet system. Thus, the power of arrest and confinement is taken away from those trying to exercise it. Consequently, Ivan's attempt to make a citizen's arrest fails miserably when he races across Moscow in pursuit of Woland after Berlioz's beheading. Similar luck is experienced by the secret agents, who come to arrest Woland several times but find no one in the apartment. When they do find someone, it is the cat who turns out to be invulnerable to their nets and bullets, thereby making fools of them in a grotesque duel. The same type of physical liberation gives Margarita the power to fly through the air on a broomstick and take revenge on the critic Latunsky who was instrumental in the Master's downfall. 
Many other instances can be cited, but the most important act of physical liberation through Woland's power is the liberation of the two lovers from the actual constraints of life itself. By physically removing the Master and Margarita from Stalinist Russia, Woland incorporates his own dream-like quality into their reality and turns the oppressive reality of Moscow into a remote dream. This "liberation from life itself" theme is related to the last years of Bulgakov life. He knew that he was dying of kidney failure as feverishly tried to complete Master i Margarita, and death to him was a release not only from the burden of the Soviet system but also from the burden of living in pain:

Боги, боги мои! Как грустна вечерняя земля! Как таинственны туманы над болотами. Кто блуждал в этих туманах, кто много страдал перед смертью, кто летел над этой землей, неся на себе непосильный груз, тот это знает. Это знает уставший. И он без сожаления покидает туманы земли, ее болотца и реки, он отдается с легким сердцем в руки смерти, зная, что только она одна успокоит его (Bulgakov, 1969: 476).

This remarkable lyrical passage, marking the release of the two lovers from Moscow and from life, appears as a haunting plea for release which Bulgakov did manage to experience before his death - vicariously, through his liberatordevil.

It ought to be mentioned that the two lovers liberated through Woland's magic acquire the power to liberate others. Thus, both Margarita and the Master become liberators, for Margarita rids Frida, the infanticide, of her haunting handkerchief, while the Master gives Pontius Pilate the freedom to leave his two-thousand-year-old prison and join Yeshua in a world beyond this one.

Woland's magic is, however, but a means to fulfilling his ultimate mission: the liberation of love, faith and art. All three are intertwined in Master i Margarita, and they represent exactly that which was lacking or suppressed in the Soviet Russia of the 1930s. The symbol that embodies love, faith and art is the Master's novel. It is inspired by Margarita's love, it expresses the artist's faith 
in honest self-expression and it represents a sincere act of creation which is true art. Thus, the liberation of the novel is the devil's main function in Master $i$ Margarita. Being a modernist devil, Woland strives to make the artist, along with his art, independent of dogma and of the Stalinist reader - both of which condemn the Master and his novel. Woland begins the process of liberating the novel the moment he arrives in Moscow: although the Master has been driven to burn the manuscript, one of its chapters is resurrected by Woland during his religious debate with Berlioz.

In her monumental book on Bulgakov, Ellendea Proffer writes that in "Master $i$ Margarita the destruction of religion is a submerged theme which links many seemingly disparate elements, ranging from Berlioz's antireligious propaganda to [Mathew the Levite's] parchment" (553). Berlioz represents the atheism of the materialist ideology propagandized by the Communist State, while Mathew's twisting of Yeshua's message corresponds to the way the church, the gospels and many practicing Christians have misunderstood and/or abused the presumed teachings of the historical Jesus. These two approaches to Christianity are "seemingly disparate," but in reality they are both a form of intellectual oppression. Therefore, Woland begins his role of liberator by defying these two distorted views of Christianity's origins. The moment he appears on Patriarch's Ponds, he challenges Berlioz's attempts to disprove not only Christ's divinity but also his historicity by quoting a work of art: the Master's novel. In doing so, Woland simultaneously liberates the novel from oblivion and religion from dogma. And so Jesus is presented to us not in a socialist realist context or a dogmatic Christian view - both of which deal with reality as it should be (or should have been...) - but as he appears to the artist.

The opposition of honest art to the art of dogma (socialist realism in this case) is pursued throughout the entire novel as if to justify the liberation of art by the devil. As the redeemer of real art, Woland resolves what A. Colin Wright 
calls "the conflict between the artist and the apparatus of the state" (267). This is done in two phases: a) the representatives of socialist realism are cast down, and b) the artist is redeemed - along with his work. Bulgakov chose two bastions of socialist realism as targets for Woland: theatre and literature. The heads of these institutions, Berlioz and Likhodeiev, are placed in one apartment and then eliminated by the devil. And so Master i Margarita begins with the decapitation of socialist realism, literally - in the case of Berlioz whose head is actually cut off by a streetcar, and metaphorically - in the case of Likhodeiev who is projected to Yalta.

The beheading of socialist realism continues as Likhodeiev's assistants, Rimskii and Varenukha, are also neutralized: Rimskii is frightened out of his mind and out of the theatre, while Varenukha is turned into a vampire. By having Bengalskii (the MC at the Variety Theatre) decapitated, Woland completes the cycle: all the parties responsible for theatre censorship are eliminated. Now the way is clear to exposing the substance of Soviet theatre. This is done by reversing the roles of the actors and the audience: the audience is observed from the stage by the performer who happens to be the devil. The result of this reversal is another reversal: suddenly homo sovieticus is shown as he really is and not as he should be. So by taking the actor off the stage, Woland takes socialist realism off the stage and shows that it is a lie. Homo sovieticus is made to reveal his greed - when fights break out in the audience over money that begins to fall out of the air; his vanity - when women rush to get their French dresses, shoes and perfume at the Paris fashion shop on stage; and his corruption - when Koroviev reveals that Arkadii Apollonovich Sempleiarov, the head of the Moscow Theatres Acoustics Commission and supposedly a model of Soviet respectability, commits adultery and gives good roles to the women he sleeps with. Woland sums it all up, making a simple Mensch out of the Soviet Übermensch: 
- Ну что же... они - люди как люди. Любят деньги, но ведь это всегда было... Человечество любит деньги, из чего бы те ни были сделаны, из кожи ли, из бумаги ли, из бронзы или из золота. Ну, легкомысленны... ну, что ж... и милосердие иногда стучится в их сердца... обыкновенные люди... в общем, напоминают прежних... квартирный вопрос только испортил их... (Bulgakov, 1969: 159-160).

Woland's show at the Variety Theatre is called "Черная магия $и$ ee разоблачение." This is of course a sarcastic title, since a total reversal takes place during the show, and, instead of being exposed, the black magic serves to expose Soviet reality through the audience. As Ellendea Proffer puts it, "feats of magic in the world of the Soviet citizens of the 1920s and 1930s are in some ways less remarkable than their actual daily life, with purges, nighttime disappearances, and legalized violence" (555). Unfortunately, Michael Glenny, an early translator of Master i Margarita, did not grasp the importance of "разоблачение" as a Soviet concept, translating the title of Woland's magic show as "Black Magic Revealed" (Bulgakov, 1984: 129). Glenny proceeds to use the verb "reveal" throughout the entire scene, thus neglecting the extratextual significance of the original "разоблачение" and the resulting word-play. "Разоблачать" ("to expose" in Russian) is crucial here because it is a very obvious allusion to the way this verb was used during the Stalinist purges. The Soviet Union of the 1930s was a stage for countless public witch hunts and show trials where people would be "exposed" as agents in the service of capitalist spy networks or subversive elements bent on undermining the communist State. This notion of "exposing" the so-called real identity of an enemy is reversed by the devil, for he ends up turning the tables on the system that normally did this exposing.

After systematically exposing all the weaknesses of the socialist realist Übermensch, the devil crowns this reversal by exposing the very concept of exposing. This is done at the end of the show when the above-mentioned Arkadii Apollonovich Sempleiarov, the head of the Moscow Theatres Acoustics Commission, demands that the incredible tricks be exposed: "Всё-таки 
желательно, гражданин артист, чтобы вы незамедлительно разоблачили бы перед зрителями технику ваших фокусов, в особенности фокус с денежными бумажками [my italics-V.T.]" (Bulgakov, 1969: 164). То this the devil replies by publically exposing Sempleiarov himself as an adulterer and a hypocrite, crowning this ultimate reversal by the following play on the verb "expose": "Вот, почтенные граждане, один из случаев разоблачения, которого так назойливо добивался Аркадий Аполлонович!" (Bulgakov, 1969: 166) Needless to say, after this final reversal the demonic carnival of liberation triumphs, and Woland's scandalous show puts the Variety Theatre and socialist realism on stage out of commission.

After decapitating Berlioz, the bureaucratic side of Soviet literature, Woland goes after the literature itself, represented by Ivan Bezdomny. The poet is committed to a mental hospital where a reversal, similar to the one at the Variety Theatre, takes place: whereas everyone used to listen to Ivan's propagandistic rhetoric (poetry) in print, a deaf ear is turned to the truth he tells about Woland. By having Ivan locked up in Stravinsky's mental hospital, Woland achieves a two-fold liberation: when Ivan realizes that his poetry is not art but dogma and decides to quit writing, both he and his potential readers are liberated. Later on, Woland makes it possible for Margarita to ransack Latunsky's apartment, which is a strike at Soviet literary criticism and censorship and what A. Colin Wright calls "a perfect piece of wish-fulfilment" (267) on the part of Bulgakov who was hounded by critics of Latunsky's ilk just like the Master.

The final coup de théâtre comes when Koroviev and Behemoth symbolically bring down the entire institution of literary socialist realism by burning down the Griboiedov House. Before this ultimate act of what Lesley Milne so aptly calls Woland's "poetic justice" (25), Koroviev and Behemoth - as if in justification of the impending fire - demonstrate the worthlessness of the Soviet literary institution. When they are stopped at the entrance to the 
Griboiedov House and asked to show their ID's, Koroviev replies: "Вовсе не удостоверением определяется писатель, а тем, что он пишет" (Bulgakov, 1969: 445). This ironic argument obviously falls on deaf ears.

The notion that Bulgakov's devil is a challenge to the socialist realist institution is confirmed by John Bushnell's analysis of the graffiti on the walls around apartment 50 (see above). When a production of Master i Margarita was cancelled at the Taganka Theatre in Moscow in 1984, and the stage director, Yury Liubimov, was replaced by Anatoly Efros, the following inscription appeared on the wall: "Эфрос, тебе говорили не лги по телефону (Азазелло)" (Bushnell: 508). This of course is the line spoken in Master $i$ Margarita by Azazello to Varenucha. In this curious twist, the graffiti devil is trying to liberate not only art in general but also himself since the cancellation of the play in which he is the main character is a threat to his existence. One almost gets the feeling that the novel continues, and its characters are still with us.

The second phase of the artistic liberation carried out by Woland is the liberation of the artist and his work. This is of course the 'resurrection' of the Master at Margarita's request. The writer, symbolizing the thousands of Soviet artists who had suffered his fate in Russia of the 1930s, is yanked out of the mental hospital. By making the Master nameless, Bulgakov extends the significance of his liberation beyond the sociopolitical context of the moment. The Master stands for the true artist, and his liberation from the confines of dogma is the traditional role of the devil who is supposed to be a patron of the arts. "Рукописи не горят" (Bulgakov, 1969: 363) is perhaps the most famous line of the entire novel and the most significant. These are Woland's words as he returns the burnt manuscript to the Master, crowning this ultimate act of liberation: true art is freed of the yoke of socialist realism. Furthermore, since the Master's novel is the metafictional embodiment of Bulgakov's novel, Woland appears to liberate two works of art simultaneously. It is at this point 
that Bulgakov's modernist devil has fulfilled his traditional role and may now depart, which is exactly what he does.

The above discussion may lead one to view Bulgakov's devil as an allegory of the perfect dream: the blue sky that makes the prisoner's mind roam as he looks out of his cell window. As A. Colin Wright says: "Ultimately in this novel, justice triumphs . . . Ill-doers are punished . . . The greedy have their gains taken away from them. Fools and hypocrites are discomfited" (267). Woland seems to be a new kind of devil indeed, a devil with no apparent catch: bringing with him his mythical form, he has shed the guilt of repressed drives traditionally associated with Satan. He appears to be Lucifer in the true sense of the Latin: the light-bearer.

However, this is only an illusion, and therein lies the profoundly tragic quality of Master i Margarita. Bulgakov chose his liberator to be not an incredibly clever and powerful human being but a mythical being whose mythical nature stresses the unreality of its impact on reality. The more incredible Woland's feats are, the more they remind us of his own incredibleness. The freedom of Woland is as unattainable as the freedom of the blue sky seen by the abovementioned prisoner who can never forget that he is looking at it through the bars of his cell window. And so, Bulgakov's devil is a symbol of hope and hopelessness at the same time, reflecting the chaos of the modern and modernist world. Woland is like a carrot on a stick in front of a donkey: he is an allegory of freedom to be sure, but in Russia of the 1930s freedom was just as unreal as the devil or modernism.

This becomes evident at the end of the novel when we realize that Woland's challenge to socialist realism has had no effect whatsoever. As soon as this modernist devil leaves Moscow, the Variety Theatre and the Writers' Union, which he seemed to have brought down, are raised to their previous socialist realist heights. Although the devil has beheaded both institutions and burned 
one of them to the ground, they are alive and well after Woland's departure as we learn from the epilogue. Because Bulgakov's devil is a caraivalesque one, his impact is just as temporary as that of medieval carnival which was simply a way of letting off steam. Therefore, I believe that socialist realism triumphs in Master i Margarita, since its institutions are restored while the Master, just like Bulgakov, dies and never sees his novel published. The liberation of love, faith and art is a failure because in order to be free, the lovers have to die, taking with them their faith and their art. Therefore, I do not see Master i Margarita as a "comedy of victory", as Lesley Milne calls it, for as soon as the supernatural world is removed, no trace of the honest artist or his honest art remain in the natural, anti-modernistic world. Thus, instead of a "comedy of victory", Bulgakov's novel embodies the agony of modernism in the Soviet Union of the 1930s.

\section{Works Cited}

Bakhtine, Mikhaïl. Trad. Andrée Robel. L'oeuvre de François Rabelais et la culture populaire au Moyen Age et sous la Renaissance. Paris, 1970.

Bulgakov, Mikhail. Мастер и Маргарита. Frankfurt/Main, 1969.

Bulgakov, Mikhail. The Master and Margarita. Trans. M. Glenny. London, 1984.

Bushnell, John. "A Popular Reading of Bulgakov: Explication des Graffiti." Slavic Review 47 (Fall 1988) 2: 502-511.

Curtis, Julie. Bulgakov's Last Decade: The Writer as Hero. Cambridge, 1987.

Milne, Lesley. The Master and Margarita: A Comedy of Victory. Birmingham, 1977.

Proffer, Ellendea. Bulgakov: Life and Work. Ann Arbor, 1984.

Shvartz, А. «Жизнь и смерть Михаила Булгакова» Континент 54 (1987).

Sahni, Kalpana. A Mind in Ferment: Mikhail Bulgakov's Prose. Atlantic Highlands N.J., 1986.

Vatter, Hannes. The Devil in English Literature. Bern, 1978.

Wright. A. Colin, Mikhail Bulgakov: Life and Interpretations. Toronto, 1978. 